\title{
Classical Philology and Racism: A Historiographical Critique of Bernal's Black Athena and the Assumption That the Nineteenth-century Classical Philology Was Strongly Governed by Racism
}

\author{
By Thomas Brobjer*
}

In this paper I show that the nineteenth century classical philology was much less governed by racist values than Martin Bernal argued in his Black Athena (1987) and which many thereafter assume to have been the case. I criticize Bernal's lack of evidence and examine a number of thinkers and texts from the period c. 1850 to 1920, essentially randomly selected, who and which show few signs of being governed by racism when discussing Greek culture and civilization in comparison with Egyptian and other early civilizations.

There are two main themes in Martin Bernal's three volume Black Athena project $(1987,1991,2006)$. Firstly, to show that Egyptian and other southern and eastern Mediterranean influences on ancient Greece have been wrongly denied or strongly underemphasized by scholars since about 1800 . The reasons for this are claimed to be external to scholarship, and as the primary cause he points at nineteenth century racism. This view is still echoed today. Secondly, Bernal attempts to show the existence and importance of especially Egyptian influence and colonisation on prehistoric and ancient Greece.

As an intellectual historian I will be concerned only with the first theme. This is the main theme discussed by Bernal in the first volume of Black Athena (1987) called The Fabrication of Ancient Greece 1785-1885. In essence, Bernal's argument is simple and based on Kuhn's scheme of paradigms. From the classical period until approximately 1800 there was a general consensus in regard to the origin of Greek civilization. This consensus consisted in a belief that the Greeks had been civilized by Egyptian and Phoenician colonization and of the importance of later Egyptian influence on Greek philosophy and thinking. Bernal calls it the Ancient Model. Up to the eighteenth century there was no doubt, says Bernal in his conclusion to volume 1, that "Egypt was seen as the fount of all 'Gentile' philosophy and learning, including that of the Greeks; and that the Greeks had managed to preserve only some part of these."1 During the first half of the nineteenth century this model was rejected and a new one took its place. This supposedly new view Bernal calls the Aryan Model and he characterizes it by stressing that the "notion that Greece was a

\footnotetext{
*Professor, Uppsala University, Sweden.

1. Martin Bernal, Black Athena: The Afroasiatic Roots of Classical Civilization. Volume 1: The Fabrication of Ancient Greece 1785-1985 (London, 1987), 440.
} 
mixed culture that had been civilized by Africans and Semites became not only abominable but unscientific." ${ }^{2}$

The scholarly and learned interest in antiquity, and especially Greek antiquity, increased immensely during the nineteenth century, during the time of the birth of modern classical philology, particularly among German scholars. With a great revival of interest and knowledge about Greek antiquity changes in the views about the Greeks are of course to be expected. However, Bernal states that the critique and decline of the Ancient Model is to be explained by external factors alone, i.e. that new knowledge and new methods were of no consequence. ${ }^{3}$ For the rise of the Aryan Model one important 'internal' development was fundamental: Greek was an Indo-European language. Bernal accepts this and his own view is not that of the Ancient Model but one which he calls the Revised Ancient Model which "accepts a number of features from the Aryan one, including the central belief that at some time a significant number of Indo-European speakers came into Greece from the north." (p. 439).

The Aryan Model, according to Bernal, ruled supreme until the Second World War, continued thereafter but increasingly without its "ideological underpinnings of racism and anti-Semitism". Since the data do not fit his claim that the Aryan Model was hegemonic, Bernal occasionally uses more careful language. For example, he states:

"In fact, for much of the nineteenth century the two [i.e. the Ancient and the Aryan Models] coexisted in what I call the Broad Aryan Model. [...] the supporters of the Aryan Model have been concerned with racial hierarchy and racial purity, and the idea of Egyptian and Phoenician colonization always seems to have been distasteful to them." ${ }^{4}$

On the whole, Bernal's claims seem not implausible. That values, in this case racist and related values, can and often do play a role in the interpretation of history is clear. The plausibility of his case - together with a general 'humility' and the dislike to defend something that could be associated with racism - are important reasons for the lack of resistance to, and rejection of, Bernal's claims in regard to historiography, and the assumption that nineteenth century classical philology was governed by racism is common today. ${ }^{5}$ This is

2. Ibid, 441. Compare p. 292: "As first the Egyptians and then the Phoenicians were increasingly perceived as 'racially' inferior, the Greek legends of their having not only colonized but civilized 'sacred Hellas' became not merely distasteful but paradigmatically impossible."

3. Ibid, 441: "I see this destruction of the Ancient Model as entirely the result of social forces such as these, and the requirements put upon the Ancient Greeks by 19th-century Northern Europeans. My belief is that no internalist force - or advance in the knowledge of Ancient Greece - can explain the change." See also p. 330.

4. Bernal, 330-331. Bernal shifts between using the Aryan Model and the Broad Aryan Model without specifying reasons. Mostly, and almost always when making general statements, he refers to the Aryan Model. Unfortunately, he also does not define the Broad Aryan Model clearly, in particular, it needs to be distinguished from his own Revised Ancient Model. The difference between them is not clear.

5. See, for example, Ali A. Mazrui, "The Re-Invention of Africa: Edward Said, V. Y. Mudimbe, and beyond", Research in African Literature 36 (2005): 68-82. 
so in spite of the many flaws of the book. Bernal's thesis has received important critique, but, nonetheless, continues to be frequently perceived as true. Examples of earlier historiographical critiques are: Frank M. Turner's "Martin Bernal's Black Athena: A Dissent" in Arethusa 22 Special Issue (1989), 97-109, P. O. Kristeller's "Comment on Black Athena", J. Hist. of Ideas 56 (1995), 125-27, R. Palter's "Black Athena, Afrocentrism, and the History of Science", History of Science, 31 (1993), 227-87, Josine H. Blok's "Proof and Persuasion in Black Athena: The Case of K. O. Müller", J. Hist. of Ideas 57 (1996), 705-724 and David Gange's "Religion and Science in Late NineteenthCentury British Egyptology", The Historical Journal 49 (2006), 1083-1103, as well as two books from 1996 associated with Mary Lefkowitz. ${ }^{6}$

Two persons with the same values, for example racist values, can nonetheless write studies of a very different quality. One can conscientiously examine the evidence, give reasons for her or his argumentation, conclusions and values and treat seriously also arguments that go counter to her or his own values. The other can select facts and build his case on preconceived notions. Bernal, who makes no secret that he is deeply engaged in 'politically correct' end-of-the-20th-century values, unfortunately uses for the historiographical part of his book procedures which are more akin to the second than the first manner. ${ }^{7}$ To this should be added that Bernal uses almost exclusively externalistic and circumstantial evidence and he refers to very few primary sources.

In this paper I will question Bernal's historiography. I will do so by examining the references to the origin of Greece and the discussion of the influence on the Greeks, especially the Egyptian influence, by a number of thinkers and classical scholars during the second half of the nineteenth century and the first half of the $20^{\text {th }}$.

6. In his sharp but friendly review Turner explicitly criticizes Bernal on two of the major points of concern in the present article, i.e. the lack of specific analysis of what classical scholars actually has said and the need to show that there is a direct connection between racism and the writing of ancient history. In regard to the first point Turner writes: "it is this consistent absence of particularistic analysis that mars and from the standpoint of intellectual history almost fatally flaws the credibility of Professor Bernal's argument as it is presented." (p. 104). Turner, however, does not perform any such analysis or give any counter-examples. To a large extent the purpose of this paper is to do so.Kristeller, in his much more hostile review, explicitly claims that most of the scholars during the early part of the twentieth century did not support the Aryan Model and did not deny the importance of non-Western cultures for the ancient Greeks.

7. During lectures held at Uppsala University during the spring of 1994 Bernal stated: "My main motive was to attack racism among 19 and 20th century classicists". There is, however, a risk that these sorts of motives and values simply are the result of a different set of prejudices based on the idea of progress - a special form of Whig history - the nineteenth century was racist, bigoted and unscientific, we know better. Bernal even ends his book with the predication that "a revised form of the Ancient Model will be generally accepted early in the next century". To me, that seems not unlikely, but the reason is that I am not convinced that this has not, more or less, always been the accepted view. Bernal seems to have fabricated, or at least exaggerated, the racism and the effect of this racism in nineteenth century classical philology. It is thus an example of what is called a straw man argument. 
The authors and texts discussed are not the result of a systematic investigation of the views of classical scholars, but mostly reflect classical philologists and thinkers I have encountered in my research. While examining the views of, say, thirty scholars and philosophers, I have not come across a single one who explicitly denies Egyptian influences on the Greeks. However, for a fairly large number of cases I have not found any opinion expressed at all on the questions discussed here - which is not all that surprising since, at least in the nineteenth century, there seems to have been a very limited interest in the origin of Greek culture and civilization.

One of Bernal's major points is that the nineteenth century classicists were over-critical and dismissed written records and myths even when there were no real ground for doing so. ${ }^{8}$ Bernal's critique may in many cases be justified, though the nineteenth century over-critical approach is understandable as the result of historicism, new information and methods, the fact that classical history and philology became more and more established academic disciplines and departments, and as a reaction to the rather gullible attitude towards the Greeks in previous centuries. However, Bernal suggests that this over-critical approach was used for racist reasons and in fields relevant for the denying of external influences on the Greeks. But, in fact, this over-critical approach was used in all fields of classical philology - whether relevant for racism or not. For example, during the second half of the nineteenth century the genuineness of almost every Platonic dialogue was called into question.

All this means that what he does is to substantiate (or suggest) that his case is plausible - he gives, for example, a large number of 'externalist' reasons why it should be so, such as the Greek War of Independence in the 1820s, a general political reaction to the French Revolution, nationalism, increasing racism, the idealization of Greece, etc. - but he does not actually substantiate that racist values did in fact influence classical philology. In his summary Bernal claims: "The main point I have been trying to make throughout this book is that the Ancient Model was destroyed and replaced by the Aryan Model" (p. 442) and that the main cause for this was systematic racism. However, only three names are mentioned to substantiate this: Abbé Petit-Radel, K. O. Müller and William Smith, and only one of them, Müller, is discussed in any detail. Müller was an important German classicist, but Petit-Radel and Smith were neither important nor influential. If they were typical, this has not been shown, nor does Bernal claim this specifically. A few other 'classicists' are mentioned: Hegel, Marx, Heeren and Niebuhr as transitional figures and Thirlwall, Grote and Curtius, but none of them fit Bernal's description of the Aryan Model, with the possible exception of Ernst Curtius.

In fact, Bernal's case is almost exclusively based on his interpretation of Müller and his studies: "The Aryan Model - which followed his success - was

8. For example, in the case of George Grote, Bernal writes: "Momigliano claims that because of his 'neutrality', Grote's views on mythology have in no way been invalidated by later archaeological discoveries that would seem to confirm legendary accounts. This excuse does not apply if, as I maintain, his views were sceptical. [...] Nevertheless, Grote's contempt for tradition's failure to satisfy the requirements of 'proof' has been immensely influential", Bernal, 328-329. 
constructed within the new paradigms" (p. 32). ${ }^{9}$ Even one of Bernal's quotations from Müller indicate that Müller was far from denying all or substantial influences from the East and thus should probably not be regarded as supporting the Aryan Model: "What Müller outlawed was any special relationship between Greek and Eastern myth. Indeed, as he put it, 'the entire book is opposed to the theory which would make the majority of myths importations from the East.'" (p. 313). ${ }^{10}$ Blok has examined the case for racism concerning Müller in much greater detail and shown that Bernal's account "cannot be regarded as acceptable history". ${ }^{11}$

My investigation concentrates on the question of the existence and hegemony of the Aryan Model 1850-1920, especially in regard to Egyptian influences. This is mainly discussed in chapter VI (Hellenomania, I: The fall of the Ancient Model, 1790-1830) and VII (Hellenomania, 2: Transmission of the new scholarship to England and the rise of the Aryan Model, 1830-60) in Bernal's book. Bernal does not continue the investigation and argument about the denial of Egyptian influences after 1860, but clearly implies that the reason for this was that the Aryan Model ruled supreme. I will show, by example, a number of individuals, and more general texts (encyclopaedias), who and which in no way seem to support or fit the Aryan Model. Of course, a number of examples do not disprove Bernal's claims - only make them questionable but, in fact, the number of examples given here for which the hypothesis of a general denial of Egyptian influences on the Greeks does not fit, is larger than the ones cited by Bernal in support of his argument.

John Stuart Mill, like most thinkers in the nineteenth century, was much more concerned with ancient Greece than with ancient Egypt. In fact, Mill was one of the great proponents of the classical tradition. He learnt Greek early and wrote extensively about Greece and Greek culture, philosophy and politics. A notable example of this attitude is seen in his claim that "the battle of Marathon, even as an event in English history, is more important than the battle of Hastings". ${ }^{12}$ The almost only reference to ancient Egypt that Mill makes, written in 1850, far from confirming the Aryan Model which according to Bernal was hegemonic at that time, in fact claims the opposite and could almost have been said by Bernal himself: "The original Egyptians are inferred, from the evidence of their sculptures, to have been a negro race: it was from negroes, therefore that the Greeks learnt their first lessons in civilization; and to the

9. Compare: "Thus, after Müller, all 'reputable' scholars have worked in what I call the 'Broad Aryan Model'", 313).

10. Bernal is not clear as to whether Müller belongs to the Aryan Model, as implied by his central place in the book, by the subtitle of the book and the summary, or if he belongs to the 'Broad Aryan Model' as indicated in the text (p. 308-316). The problem is that if he is not classified as one of those who belong to the Aryan Model, then Bernal does not name a single person who is (with the possible exception of Curtius, but this is never clearly stated), while repeatedly referring to this as the main view in the second half of the nineteenth century.

11. Josine H. Blok, "Proof and Persuasion in Black Athena: The Case of K. O. Müller," J. Hist. of Ideas 57 (1996): 708.

12. Collected Works of John Stuart Mill, Vol. XI (Toronto \& London, 1978), 273, that is, in the first page of Mill's review of Grote's History of Greece. 
records and traditions of these negroes did the Greek philosophers to the very end of their careers resort (I do not say with much fruit) as a treasury of mysterious wisdom."13

Twenty and thirty years later Jacob Burckhardt held his famous lectures on the history of Greek culture. ${ }^{14}$ These lectures reflect Burckhardt's attempt to understand the Greek spirit and are as such almost hagiographic. Even so, Burckhardt in no way denies Greek indebtedness to other older cultures: "We shall not deny that the Greeks, directly or indirectly, learned many things from these other peoples" (p. 323), "unknowingly they derived so many things from these [Babylonian and Assyrian] cultures" (p. 116) and "the plastic representation [...] Here too the Orient paved the way" (p. 142) and he claims that Doric and Ionic art were derived from Egypt and the Orient (p. 151 and 153). He, of course, did not exclude religion, in respect to which he claims that Herodotus derived the names of the Hellenic gods and the Greek cult ceremonies "from the Egyptians, perhaps in the main correctly, for they were of great antiquity in Egypt and introduced into Greece much later" (p. 333).

Nor does Burckhardt in any way deny Phoenician influences: "Before the Greeks, the Phoenicians had already founded poleis, i.e., city communities, city states, with bodies of laws. [...] In many other respects the early impact of Phoenician culture on Greek life is recognized; we may assume that Thebes was originally a Phoenician city on what later became Boeotian territory. At all events, the Greeks must have had early knowledge of the cities along the Phoenician coast and of the colonies they planted." (p. 5). Later on he claims that the Phoenicians can be regarded as predecessors of the Greeks (p. 326, compare also similar statements on page 277). ${ }^{15}$

One of the most attentive listeners to, at least, some of Burckhardt's lectures was his colleague, the classical philologist Friedrich Nietzsche. He became the philosopher who perhaps more than any other proclaimed the importance of Greek culture and values in modern times. His philosophy, and in particular his revaluation of all values, can to a large extent be regarded as an attempt to return to the ancient Greek values. For example, he claims that the Greek man of antiquity "alone has hitherto been 'the man that has turned out well"'16 and he refers to Greek culture as a standard: "When the Greek body and the Greek soul 'bloomed' [...] there arose that mysterious symbol of the highest world-affirmation and transfiguration of existence that has yet been attained on earth. Here we have a standard by which everything that has grown up since is

13. Collected Works of John Stuart Mill, Vol. XXI (Toronto \& London, 1978), 93.

14. These lectures, Griechische Kulturgeschichte, were held for the first time in 1872 and for the sixth and last time in 1885/6. They were posthumously published in four volumes 1898-1902. The quotations below are from the English translation of the abridged version of Burckhardt's lectures, History of Greek Culture (London, 1963).

15. Burckhardt refers to, and quotes from, K. O. Müller several times during the lectures but never in regard to the origin of Greek culture or on the question of influences from other cultures.

16. Friedrich Nietzsche, Sämtliche Werke: Kritische Studienausgabe, vol. 11 (KSA 11), 37[8]. Also published as The Will to Power, trans. W. Kaufmann (London, 1967): section 957. 
found too short, too poor, too narrow."17 However, this romantic immense emphasis on the Greek culture as an example [Vorbild] does not mean - in spite of his praise of the value and importance of creativity - that he denied that the Greeks has built on, and borrowed much from, other cultures. "Not to create forms but to borrow them from abroad and to transform them into the fairest appearance of beauty - that is Greek" ${ }^{18}$ In fact, he does the opposite and is thus as far removed from the Aryan Model as one can be. "They [the Greeks] never lived in proud isolation; on the contrary, their 'culture' was for a long time a chaos of foreign ideas and concepts - Semitic, Babylonian, Lydian and Egyptian; and their religion a general conflict among the gods of the whole Orient". ${ }^{19}$

In Philosophy in the Tragic Age of the Greeks, written in 1872 but never completed for publication, he repeated that "nothing would be sillier than to claim an autochthonous development for the Greeks. On the contrary, they invariably absorbed other living cultures. The very reason that they got so far is that they knew how to pick up the spear and throw it onward from the point where others had left it" (p. 30). Several of Nietzsche's comments refer, not only to his own views, but also explicitly to views common in the nineteenth century: "It has been pointed out assiduously [...] how much the Greeks were able to find and learn abroad in the Orient, and it is doubtless true that they picked up much there" (p. 29). Similar statements are found in Nietzsche's lectures at Basel University. Here not only does he mention Greek borrowing from other cultures, but also briefly summarizes different hypotheses about the origin of Greek mythology. ${ }^{20}$

These are not merely general comments in Nietzsche's case. In fact, he seems to emphasize Egyptian and Phoenician influences as much as Bernal does: "The constitution of the polis is a Phoenician invention; even this was copied by the Greeks. For a long time, like happy dilettantes, they studied everything around them; even Aphrodite is Phoenician. And they refuse to disown their importations, the nonindigenous." ${ }^{21}$ He emphasizes the Egyptians and the Egyptian heritage with even more strength: "The Egyptians are a much

17. Friedrich Nietzsche, Sämtliche Werke: Kritische Studienausgabe, vol. 11, KSA 11, 41[7], written in August-September 1885. Also published as The Will to Power, WM, section 1051. This whole section is pertinent. In it Nietzsche, for example, claims that "Dionysos is a judge" in the sense that antiquity is the judge of modernity.

18. Friedrich Nietzsche, Human, All Too Human, Vol. II.1, trans. R. J. Hollingdale (Cambridge, 1986), section 221.

19. Friedrich Nietzsche, History in the Service and Disservice of Life, trans. Gary Brown (New Haven, London, 1990), section 10.

20. Friedrich Nietzsche, Werke, Kritische Gesamtausgabe (KGW), II.3 (Berlin, New York, 1993). The series of lectures entitled 'Encyclopaedie der klass. Philologie', held in 1871 and possibly also in 1873/74. The review of different hypotheses of the origin of Greek mythology is on page 410, in the section 'Über Religion und Mythologie der Alten'. Hermann's and K. O. Müller's hypothesis that it was an internal Greek development is mentioned as one hypothesis among others. Attempts to derive it from Egypt and Phoenicia are also mentioned. See also, for example, 428.

21. Friedrich Nietzsche, "We Classicists," trans. W. Arrowsmith in Unmodern Observations, ed. W. Arrowsmith (New Haven \& London, 1990), 360. (This is equivalent to KSA 8, 5[65] in the German standard edition.) In the same fragment Nietzsche has no problem to also assert: "The Greeks are the only people of genius in world history". 
more literary people than the Greeks. Here I disagree with Wolf." ${ }^{22}$ A little later he continues on this theme: "The really scholarly [wissenschaftliche] people, the people of literature, are the Egyptians, not the Greeks. What looks like learning [Wissenschaft] among the Greeks derived from the Egyptians and later returned home to blend its waters with the old current. Alexandrian culture is a blend of Hellenic and Egyptian." ${ }^{23}$

In spite of these similarities with Bernal, Nietzsche draws completely opposite conclusions from Bernal: the Greeks have been undervalued, we must strive harder to make Greek culture not merely decorative but to let it shape our culture. Nietzsche's argument is not one of chronology but one of quality:

"The quest for philosophy's beginnings is idle, for everywhere in all beginnings we find only the crude, the unformed, the empty and the ugly. What matters in all things is the higher levels. People who prefer to spend their time on Egyptian or Persian philosophy rather than on Greek, on the grounds that the former are more 'original' and in any event older, are just as ill-advised as those who cannot deal with the magnificent, profound mythology of the Greeks until they have reduced it to the physical trivialities of sun, lightning, storm and mist which originally presumably gave rise to it. [...] Everywhere, the way to the beginnings leads to barbarism." 24

The expert on the religion in ancient Greece, Martin P. Nilsson, writes in his A History of Greek Religion (1925):

"Some students of the question have sought to connect it with the ancient religions of the East - of the Semitic world and of Egypt. Traces of Semitic and Babylonian influences upon Minoan-Mycenaean cultures are vague and difficult to detect. Not so with influences of Egypt. It can be shown that an active relationship existed between Crete and Egypt; the first efflorescence of Minoan culture in the Early Minoan Age seems to have been due to Egyptian impetus." 25

In a more general work, a world history in which Nilsson wrote the second volume, dealing with Greece and the Hellenistic kingdoms, he even less denies the influence of other cultures on the Greeks:

"The revival of the Greek art is probably due to impulses which in part had remained from the Minoan time and in part came from Egypt, but already from the beginning it [Greek art] betrays its future distinctive character [...]. The first closer acquaintance with the old culture of the Orient seems

22. Ibid, 360. This is equivalent to KSA 8, 5[66] in the German standard edition.

23. Ibid, 370. This is equivalent to KSA 8, 5[122] in the German standard edition. Wissenschaft is the normal German word for science (natural and humanistic science).

24. Friedrich Nietzsche, Philosophy in the Tragic Age of the Greeks (written in 1872), trans. M. Cowan (Chicago, 1962), 30. Compare also page 29.

25. Martin P. Nilsson, A History of Greek Religion (1925), $10 \mathrm{f}$. 
to have overwhelmed the Greeks. This resulted in the orientalising fashion during the seventh century B.C. It would be rather strange if this current only had brought with it a decorative fashion and not also influenced the spiritual life." 26

A paradigmatic view is often more pronounced in general introductions, encyclopaedias, etc. than it is in the works of individual scholars and thinkers. An examination of such general works does not sustain Bernal's claim that the common view was that Greece had not significantly borrowed culturally or linguistically from Egypt and Phoenicia.

For example, the famous eleventh edition of Encyclopaedia Britannica (Cambridge, 1910) states in a section of the article on ancient Greek history called 'Oriental Influence':

"To the question, 'What is the origin of this civilization? Is it of foreign derivation or of native growth?' it is not possible to give a direct answer. It is clear, on the one hand that it was developed, by a gradual process of differentiation, from a culture which was common to the whole Aegean basin and extended as far to the west as Sicily. It is equally clear, on the other hand, that foreign influences contributed largely to the process of development. Egyptian influences, in particular, can be traced throughout the 'Minoan' and 'Mycenaean' periods." 27

In A Companion to Greek Studies, edited by L. Whibley (Cambridge, 1905), in the chapter on "Mythology and Religion", written by E. A. Gardner, it is stated that there has been much controversy and many opinions as to what part of the religion of Greece was brought by the Greeks as their version of the common Aryan inheritance, and what part they adopted from earlier inhabitants of the land or borrowed from foreign neighbours. The book leaves the question unanswered. ${ }^{28}$

Another problem with Bernal's thesis in Black Athena is that he has a far too simplistic view of racism and how this affects one's view of the world. For example, he claims that "Philhellenism has always had Aryanist and racist

26 Martin P. Nilsson, "Hellas och de hellenistiska rikena," in Världshistorien. Part 2 (Stockholm, 1928), 180 and 182. Translations into English made by me. There are, of course, many other scholars and thinkers who do not fit the Aryan Model. Joseph Wiesner in Grab und Jenseits: Untersuchungen im ägäischen Raum zur Bronzezeit und Früher Eisenzeit (Berlin, 1938) contains twenty references to Egypt and lists a large number of similarites between details of Egyptian graves and Greek ones. G. F. Schoemann in Greichische Alterthümer (1902), for example, refers on page 387 to a thesis by Th. Bergk in which he claims: "The mystery-cults in Greece were originally, without exception, alien cults" and to a study by Foucart Recherches sur l'origin et la nature des mystères d'Eleusis (1896) in which he argues that the Eleusian mysteries came from Egypt and that Demeter was identical to Isis.

27. Edward Mewburn Walker, "Greece, History, Ancient" in Encyclopaedia Britannica (Cambridge, 1910), 441. The same text was used, at least, until and including the edition printed in 1945. Similar statements were used in several Swedish encyclopaedias written during this period.

28. E. A. Gardner, "Mythology and Religion" in A Companion to Greek Studies, ed. L. Whibley (Cambridge, 1905), 295. 
connotations" ${ }^{29}$ which is patently wrong. Not only did philhellenism (love of and admiration for ancient Greek culture) exist long before the 18th century and the time the Aryan Model came into existence, but philhellenism was also held by many individuals who were in no sense racist.

A denial of Egyptian and Phoenician influence does not necessarily imply racism, nor does an emphasis on race, even of racism, necessarily lead to a rejection of Egyptian and Phoenician influence. One example of the latter is Gustav Bang's Europeisk Kulturhistoria (1897) which, like so many books from this period, strongly emphasizes the Indo-European race of the Greeks but, at the same time, does not deny Egyptian and Phoenician influences: "The root of the Hellenic culture came from Asia and Egypt. Phoenician traders taught the Greeks measure, weight, coins and the alphabet, trade and sea-travel. The Greek gods were influenced from the east, and on travels to Persia and Egypt the Greeks fetched results that had been acknowledged in these ancient cultural lands and transferred what they learnt back to their homeland". ${ }^{30}$

Another example of the fact that there is no simple correlation between racism and the emphasis on the influence of other cultures on the Greeks is the work The Legacy of Greece (1921), edited by R. Livingstone. In the chapter on the topic of religion, written by W. R. Inge, the author strongly denies racist assumptions and values. He claims that the Greeks were not a homogeneous race, not even a race, but a culture. However, he begins his discussion of Greek religion with Homer and makes no references to external influences, in spite of the fact that religion and mythology was one of the areas where foreign influence had been most stressed. In the essay dealing with biology, it is emphasized that the Greeks inherited much from other "peoples". ${ }^{31}$

Bernal claims that up to the 18th century not only was Egypt generally regarded as the source "of all 'Gentile' philosophy and learning, including that of the Greeks," but also "that the Greeks had managed to preserve only some part of these," which implies that the Egyptians were held in higher esteem than the Greeks. He goes on to claim that "the sense of loss that this created, and the quest to recover the lost wisdom, were major motives in the development of science in the 17th century" and that it was "in opposition to the 18th century notion of 'reason' on part of the Egyptophiles that the Greek ideal of sentiment and artistic perfection was developed". ${ }^{32}$ These claims are untenable.

The number of references in European scholarly and philosophical works to ancient Egypt and the Egyptians, sometimes friendly, sometimes hostile, are minuscule as compared to the references to ancient Greece and the Greeks. The influence of ancient Egypt on European thought between the Middle Ages and the Enlightenment seems to be confined mostly to two fields: art and mysticism. In the arts there was an Egyptian revival during the middle of the 18th century (mostly affecting wall decorations) and a second one after

29. Bernal, 387.

30. Gustav Bang, Europeisk Kulturhistoria i korta drag [A Short History of European Culture] (Stockholm, 1897), 14.

31. Charles Singer, "Biology" in The Legacy of Greece, ed. R. Livingstone (Oxford, 1921), 163.

32. All the quotations come from the conclusion of Bernal's book, 439-443. 
Napoleon's Egyptian campaign, 1798-99, (affecting mainly architecture, furniture and other aspects of the applied arts). However, even during the peaks of these revivals, classical themes were generally of greater importance than Egyptian ones. ${ }^{33}$

Thomas More's Utopia (1516) is more typical of the attitude to Egypt and Greece than Bernal's claims. More tells there how some Romans and Egyptians were shipwrecked on the island a long time ago (this is the only reference to the Egyptians), while there are numerous references to the Greeks and their learning, science and philosophy. At the end the story-teller says that he believes that this happy island was a Greek colony.

Many thinkers, such as Locke and Shaftesbury, held highly critical views of the ancient Egyptians. Others, like Montesquieu, whom Bernal quotes and takes to exemplify the deep respect for ancient Egypt, praise Egypt but are much more concerned with classical Greece and the Greeks. This, of course, reflects the very different nature of the material available from ancient Egypt and ancient Greece - from Egypt no or little written material was available, while the Greek literature and philosophy was widely available and read. The ancient Egyptians could be mentioned, while the Greeks were read, discussed and studied.

Thus, Bernal has greatly exaggerated the status and importance of Egypt in European intellectual history in the period before 1800, and hence the demise of the status of Egypt in the nineteenth century (if there was one) is much smaller than claimed by Bernal.

In conclusion, it is difficult to falsify claims such as those made by Bernal in this book. He describes his own approach as "looking at flowers from horseback," i.e. his case rests on general statements with very few specific and detailed investigations. What I have attempted to do is to climb down from the horse and examine a few flowers in more detail.

In this article I have not shown that racist values played no part in classical philology and ancient history during the nineteenth century. What I have tried to show is that Bernal has not substantiated his claims that they were of utmost and primary importance. On the contrary, I have brought forth a number of thinkers and scholars who highly praised the Greeks but who seem not to have been motivated by racist values nor have they denied important Egyptian and Phoenician influences on the Greeks. Thus, if there is any truth at all in Bernal's historiographical claims - "the fabrication of ancient Greece 1785-1985" (the subtitle of Bernal's book) - this remains to be shown, and if it does exist, it was much weaker and much less dominant than he has suggested, and than many still take for granted today.

33. David Irwin, "Neo-Classicism in Art," in Dictionary of the History of Ideas, ed. P. P. Wiener (New York, 1973), vol III, 363. 


\section{Bibliography}

Bang, Gustav. Europeisk Kulturhistoria i korta drag. Stockholm, 1897.

Bernal, Martin. Black Athena: The Afroasiatic Roots of Classical Civilization. volume 1: The Fabrication of Ancient Greece 1785-1985. London, 1987.

Blok, Josine H. "Proof and Persuasion in Black Athena: The Case of K. O. Müller." J. Hist. of Ideas 57 (1996): 705-724.

Burckhardt, Jacob. Griechische Kulturgeschichte, four volumes (1898-1902). The quotations are from the English translation of the abridged version of Burckhardt's lectures, History of Greek Culture. London, 1963.

Gange, David. "Religion and Science in Late Nineteenth-Century British Egyptology." The Historical Journal 49 (2006): 1083-1103.

Gardner, E. A. "Mythology and Religion." In A Companion to Greek Studies, edited by L. Whibley, 295-345, Cambridge, 1905.

Irwin, David. "Neo-Classicism in Art." In Dictionary of the History of Ideas, edited by P. P. Wiener. Vol III, 362-372. New York, 1973.

Kristeller, P. O. "Comment on Black Athena." J. Hist. of Ideas 56 (1995): 125-27.

Mazrui, Ali A. "The Re-Invention of Africa: Edward Said, V. Y. Mudimbe, and beyond." Research in African Literature 36 (2005): 68-82.

Mill, J. S. Collected Works of John Stuart Mill, Vol. XI. Toronto \& London, 1978.

Mill, J. S. Collected Works of John Stuart Mill, Vol. XXI. Toronto \& London, 1978.

Nietzsche, Friedrich. Sämtliche Werke: Kritische Studienausgabe, vol. 11 (KSA 11).

Nietzsche, Friedrich. Werke, Kritische Gesamtausgabe, (KGW), II.3. Berlin, New York, 1993.

Nietzsche, Friedrich. The Will to Power. Translated by W. Kaufmann. London, 1967.

Nietzsche, Friedrich. Human, All Too Human. Translated by R. J. Hollingdale. Cambridge, 1986.

Nietzsche, Friedrich. History in the Service and Disservice of Life. Translated by Gary Brown. New Haven, London, 1990.

Nietzsche, Friedrich. "We Classicists". Translated by W. Arrowsmith. In Unmodern Observations, edited by W. Arrowsmith. New Haven \& London, 1990.

Nietzsche, Friedrich. Philosophy in the Tragic Age of the Greeks. Translated by M. Cowan, Chicago, 1962.

Nilsson, Martin P. A History of Greek Religion. Oxford, 1925.

Nilsson, Martin P. Hellas och de hellenistiska rikena. In Världshistorien, Part 2: Stockholm, 1928.

Palter, R. "Black Athena, Afrocentrism, and the History of Science." History of Science, 31 (1993): 227-87.

Schoemann, G. F. Greichische Alterthümer. Berlin, 1902.

Singer, Charles. "B iology." In The Legacy of Greece, edited by R. Livingstone, 163200. Oxford, 1921.

Turner, Frank M. "Martin Bernal's Black Athena: A Dissent." Arethusa 22 Special Issue (1989): 97-109.

Walker, Edward Mewburn. "Greece, History, Ancient." In Encyclopaedia Britannica Cambridge, 1910.

Wiesner, Joseph. Grab und Jenseits: Untersuchungen im ägäischen Raum zur Bronzezeit und Früher Eisenzeit. Berlin, 1938. 